\title{
Delayed tooth replantation: MTA as root canal filling
}

Sônia Regina PANZARINI(a) Celso Koogi SONODA(a) Célia Tomiko Matida Hamata SAITO(a)

Elizane Ferreira HAMANAKA ${ }^{(b)}$ Wilson Roberto POI(a)

(a)Department of Surgery and Integrated Clinics, School of Dentistry, Univ Estadual Paulista - UNESP, Araçatuba, SP, Brazil.

(b) Graduate Program in Integrated Clinics, School of Dentistry, Univ Estadual Paulista UNESP, Araçatuba, SP, Brazil.
Declaration of Interests: The authors certify that they have no commercial or associative interest that represents a conflict of interest in connection with the manuscript.

Corresponding Author:

Sônia Regina Panzarini

E-mail:panzarin@foa.unesp.br

DOI: 10.1590/1807-3107BOR-2014.vol28.0059

Submitted: Mar 20, 2014

Accepted for publication: Jun 24, 2014

Last revision: Sep 23, 2014
Abstract: MTA has been investigated as a root-end filling material. Its mechanism of action has some similarities to that of $\mathrm{Ca}(\mathrm{OH})_{2}$. The purpose of this study was to evaluate the repair process taking place in the delayed replantation of monkey teeth using calcium hydroxide and MTA as root canal filling materials. Five monkeys had their lateral incisors extracted and bench-dried for 60 minutes. After root canal preparation, the teeth were assigned to two groups according to root canal filling material: I, calcium hydroxide; and II, MTA. The same treatment sequence was followed for both groups: coronal seal, periodontal ligament removal, immersion of the tooth in $2 \%$ acidulated-phosphate sodium fluoride, irrigation of the socket with saline and replantation. Both groups exhibited replacement resorption, areas of ankylosis and absence of inflammatory root resorption. Statistically similar results $(p>0.05)$ were observed for both groups regarding replacement root resorption, but the groups differed significantly $(p<0.05)$ regarding the occurrence of ankylosis. MTA may be a viable clinical option for filling teeth submitted to delayed replantation, and is an acceptable option for treating replanted permanent teeth in order to prevent tooth resorption, particularly when dressing changes are not possible.

Keywords: Calcium Hydroxide; Periodontal Ligament; Root Canal Preparation.

\section{Introduction}

Avulsion is one the most severe forms of dental trauma because the tooth is completely displaced from its alveolar socket, causing rupture of the neurovascular bundle and pulp tissue damage. Although the possibility of pulp revascularization after tooth replantation has been reported, ${ }^{1}$ its occurrence in mature teeth is rare, and there is a direct relationship between pulp necrosis and inflammatory root resorption in replanted teeth. ${ }^{1,2}$ The literature has shown that the resorption process can be prevented or controlled with endodontic therapy based on the use of calcium hydroxide $\left[\mathrm{Ca}(\mathrm{OH})_{2}\right]$ as a temporary root canal filling material. ${ }^{2}$ The successful use of $\mathrm{Ca}(\mathrm{OH})_{2}$ as an intracanal dressing in replanted teeth is based mainly on its antimicrobial and tissue repair properties. ${ }^{3}$

Mineral trioxide aggregate (MTA) has been investigated as a root-end filling material for use in endodontic surgery, for inducing apexification, as a pulp capping material after pulp exposure or pulpotomy, ${ }^{4,5}$ and as a root canal filling material. ${ }^{6}$ It has been shown that the mechanisms of action of $\mathrm{Ca}(\mathrm{OH})_{2}$ and MTA have some similarities. ${ }^{7,8}$ 
It has been demonstrated that the long-term use of $\mathrm{Ca}(\mathrm{OH})_{2}$ - based intracanal dressings weakens the dentin structure, reducing the tooth's resistance to fracture by $23 \%-43 \%{ }^{9}$ On the other hand, changing MTA dressings is not necessary, which allows for restoring the tooth in the same session of dressing removal and reduces the possibility of fracture and coronal leakage. MTA also has some important properties for the repair of replanted teeth, such as biocompatibility, ability to induce cementogenesis ${ }^{10,11}$ and antimicrobial action. ${ }^{12}$

Considering the biological properties of MTA, the purpose of this study was to investigate the repair process taking place in the delayed replantation of monkey teeth using $\mathrm{Ca}(\mathrm{OH})_{2}$ and MTA as root canal filling materials.

\section{Methodology}

Five adult male monkeys (Cebus apella) at approximately 7 years of age and in good health, from the Tufted Capuchin Monkey Procreation Center at the School of Dentistry of Araçatuba, Universidade Estadual Paulista - UNESP, Brazil, were used in this study. The research protocol was approved by the institution's Animal Care and Research Use Committee. All guidelines regarding the care of animal research subjects were strictly followed.

The animals received intramuscular injections of ketamine hydrochloride (Dopalen ${ }^{\circledR}$; Agribrands do Brasil Ltda., Paulínea, Brazil; 15 mg/kg body weight) and benzodiazepine (Diazepan ${ }^{\circledast}$; Sigma Pharma, São Bernardo do Campo, Brazil; 0.1 mL/kg body weight) to promote sedation and muscular relaxation, respectively, and were anesthetized with an intraperitoneal injection of sodium thiopental (Thionembutal ${ }^{\circledR}$; Abbott Laboratórios do Brasil Ltda., São Paulo, Brazil; $30 \mathrm{mg} / \mathrm{kg}$ body weight).

The monkeys had their upper and lower right and left lateral incisors extracted $(n=20)$ and bench-dried for 60 minutes. Thereafter, the teeth were hand held and endodontic therapy was performed, involving access cavity preparation, pulpectomy and root canal instrumentation using the crown-down technique up toK-file\#35(Maillefer, Ballaigues, Switzerland). Throughout the preparation, the root canals were irrigated with $1 \%$ sodium hypochlorite (Aphoticário Farmácia de Manipulação, Araçatuba, Brazil) at each change of file. The instrumented canals were dried with absorbent paper points (Dentsply Ind. e Com. Ltda., Petrópolis, Brazil) and were randomly assigned to two groups: Group I, tencanalsfilled with $\mathrm{Ca}(\mathrm{OH})_{2}$ paste $(5 \mathrm{~mL}$ of propylene glycol, $5 \mathrm{~g}$ of $\mathrm{Ca}(\mathrm{OH})_{2}, 2 \mathrm{~g}$ of zinc oxide and $0.015 \mathrm{~g}$ of colophony); Group II, ten canals filled with MTA (Angelus ${ }^{\circledR}$, Londrina, Brazil). The materials were placed in the canal with a low-speed lentulo spiral \#40 (Dentsply Ind. eCom. Ltda., Petrópolis, Brazil) and the access cavities were sealed with chemically cured glass ionomer cement (Vidrion $\mathrm{R}^{\circledR}$, SS White, Rio de Janeiro, Brazil).

After completion of the endodontic treatment, the root surfaces were scraped with a \#15 scalpel blade (Solidor $^{\circledR}$, Lamedid Comercial e Serviços, Barueri, Brazil) to remove periodontal ligament (PDL) remnants. The teeth were immersed in $20 \mathrm{~mL}$ of $2 \%$ acidulatedphosphate sodium fluoride, pH 5.5 (Aphoticário Farmácia de Manipulação, Araçatuba, Brazil), for ten minutes, and then replanted after saline irrigation of the alveolar sockets. A splint made from $0.7 \mathrm{~mm}$ stainless steel orthodontic wire (Morelli, Sorocaba, Brazil) and composite resin $\left(\mathrm{TPH}^{\circledR}\right.$ Spectrum $^{\mathrm{TM}}$ Dentsply, Petrópolis, Brazil) was kept in place for 30 days. A diamond bur was then used to remove the steel wire and composite splint after this period of time.

During the course of the experiment, the animals received $0.4 \mathrm{~mL}$ of sodium cephalothin (Antibióticos do Brasil Ltda., Cosmópolis, Brazil), $0.2 \mathrm{~mL}$ of sodium diclofenac (Laboratório Delta, Carazinho, Brazil) and $0.2 \mathrm{~mL}$ of dipyrone (NeoQuímica, Anápolis, Brazil) intramuscularly. A penicillin $\mathrm{V}$ antibiotic (Pen Ve Oral $^{\circledast} 250$ mg; Eurofarma, São Paulo, SP, Brazil; 3 drops/day) was administered for seven days.

Sixty days after replantation, the animals were anesthetized with sodium pentobarbital $(30 \mathrm{mg} / \mathrm{kg}$, i. p.) and perfused transcardially. The anatomic pieces containing the teeth were removed and fixed in $10 \%$ neutral buffered formalin, decalcified in a formic acid / sodium citrate solution and embedded in paraffin. The blocks were sectioned semi-serially and six- $\mu \mathrm{m}$-thick longitudinal sections were obtained, stained with hematoxylin and eosin and examined under light microscopy by a skilled observer blinded to the treatment groups.

The longitudinal section of the root was captured by an Axio Cam MRC 5 camera (Carl Zeiss of Brazil Ltda, Rio de Janeiro, Brazil) coupled to a Stemi 2000 - C 
stereomicroscope (Carl Zeiss of Brazil Ltda., Rio de Janeiro, Brazil) at 25x magnification, enabling a panoramic view of the tooth. This image was saved as a figure in the Axio Vision 4.5 program (Carl Zeiss of Brazil Ltda., Rio de Janeiro, Brazil) and used for quantification in the ImageLab ${ }^{\circledR} 2000$ program (Computer Lab Dedicated to Dentistry, Universidade de São Paulo - USP, São Paulo, Brazil).

Initially, the total area of root dentin was measured, and then the area of resorbed root dentin was estimated. Based on the values of total dentin area and total resorbed dentin area, the rule of three was used to ascertain the percentage of the root that was compromised by root resorption. The mean values for the groups were calculated and submitted to statistical analysis.

Ankylosis was measured based on root perimeter. Initially, the total perimeter of the root was measured and then the perimeter where bone tissue was juxtaposed to cementum was measured. The percentage of ankylosed root was calculated in the same way as was the percentage of root resorption.

Digital images were obtained and compared to histological sections under the microscope to identify and select the resorption areas.

The data was statistically analyzed by the MannWhitney t-test. The significance level was set at $5 \%$.

\section{Results \\ Group I - $\mathrm{Ca}(\mathrm{OH})_{2}$}

In all the specimens, epithelial reattachment occurred at the cementoenamel junction (CEJ), and the subjacent connective tissue showed few fibroblasts and absence of inflammatory cells.

In some areas, the PDL space was filled by connective tissue with fibers arranged parallel to the root surface, and there were no inflammatory cells (Figure 1A). In other areas, throughout the three root thirds, the PDL space was filled with newly formed bone tissue (Figure 1B). Areas in which the bone tissue was in intimate contact with the cementum were also observed, characterizing the occurrence of ankylosis (Figure 1C). In all specimens, the cementum and dentin exhibited areas of resorption that were filled by newly formed bone tissue.

Only one specimen exhibited a chronic inflammatory infiltrate in the region of the apical foramen in contact with the filling material. The alveolar bone wall showed some areas of new bone formation that caused narrowing of the PDL space. In some areas, the newly formed bone filled the PDL space completely.

\section{Group II - MTA}

In all specimens, epithelial reattachment occurred at the CEJ and no inflammatory cells were found in the subjacent connective tissue. In some areas, the PDL space was narrowed and filled by connective tissue with the presence of fibers parallel to the root surface and free of inflammatory cells (Figure 1D). In other areas, the PDL space was completely filled by newly formed bone tissue.

Cementum and dentin presented areas of resorption throughout the three root canal thirds in all specimens. In some areas, the cementum was in contact with the bone tissue, characterizing the occurrence of ankylosis. In several areas, root dentin was replaced by bone tissue (Figure 1E).

Two specimens of this group presented a biological seal of the apical foramen with the presence of newly formed cementum(Figure1F). The alveolar wall presented areas with newly formed bone invading the PDL space.

\section{Statistical Analysis}

Statistically similar results $(p=0.222)$ were found for both groups regarding replacement root resorption, but the groups differed significantly $(p=0.004)$ regarding the occurrence of ankylosis (Table 1).

Table 1. Mean and standard deviation (SD) values for the histologic events observed in each group. Resorption stated as \%area. Ankylosis stated as \%perimeter.

\begin{tabular}{lccc}
\hline Histologic event & Mean (SD) & Group II - MTA & -value \\
\hline Root resorption & Group I - Ca(OH) & $6.84(1.98)$ & 0.222 \\
Ankylosis & $5.95(2.71)$ & $9.70(7.42)$ & $0.004^{*}$ \\
\hline
\end{tabular}

*Statistically significant at $5 \%$ (Mann-Whitney test). 

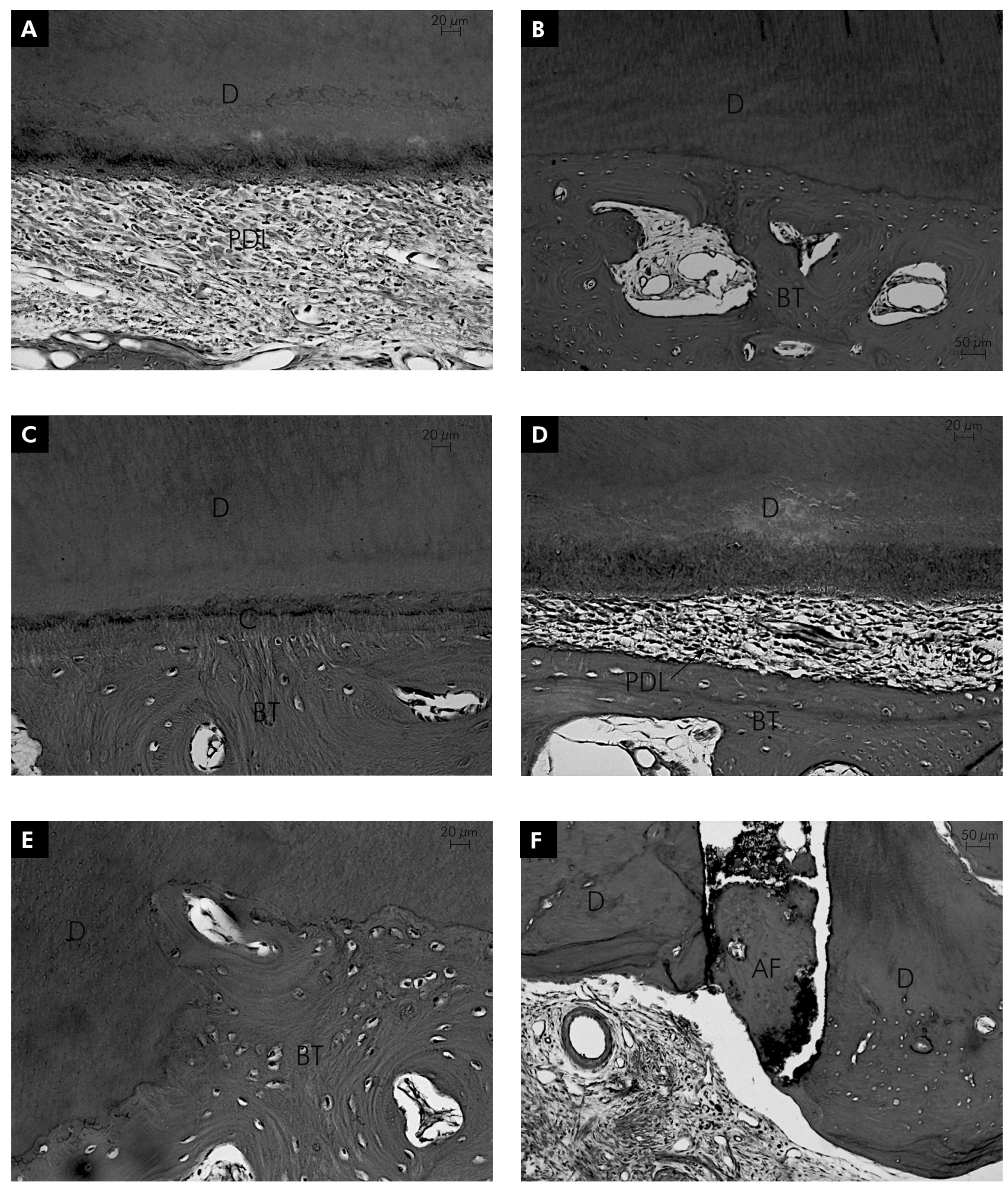

Figure 1. A - $\mathrm{Ca}(\mathrm{OH})_{2}$ - PDL space filled by connective tissue with collagen fibers parallel to the root surface. Dentin (D). H. E. B - Ca $(\mathrm{OH})_{2}$ - PDL space filled by newly formed bone tissue (BT). Dentin (D). H. E. C - Ca $(\mathrm{OH})_{2}-\mathrm{Bone}$ tissue $(\mathrm{BT})$ in intimate contact with the cementum (C), characterizing an area of ankylosis. H. E. D - MTA - The PDL space is narrowed and filled by connective tissue with collagen fibers parallel to the root surface. Dentin (D). H. E. E - MTA - Root dentin (D) replaced by newly formed bone tissue (BT). H. E. F - MTA - Biological seal of the apical foramen (AF) with the presence of newly formed cementum. Dentin (D). H. E. 


\section{Discussion}

The present study was performed according to the treatment protocol established by the International Association of Dental Trauma ${ }^{13}$ for avulsed teeth with delayed replantation. Endodontic therapy, which is the scope of this study, is an important step of the replantation clinical protocol as a means of preventing and/or treating inflammatory root resorption, which is caused mainly by pulp necrosis associated with PDL damage and contamination. ${ }^{1,14}$

The mechanism of action of $\mathrm{Ca}(\mathrm{OH})_{2}$ is well known and has been described in vitro ${ }^{15}$ and in vivo. ${ }^{16}$ The velocity of ionic dissociation of $\mathrm{Ca}(\mathrm{OH})_{2}$ may be related to the vehicle used for preparation of the paste. Because hydrosoluble vehicles permit rapid dissociation, ${ }^{3}$ they should be preferred in cases of dental trauma. For this reason, propylene glycol was the vehicle used in the present study for preparation of the $\mathrm{Ca}(\mathrm{OH})_{2}$ paste.

The high $\mathrm{pH}$ of $\mathrm{Ca}(\mathrm{OH})_{2}$ promotes an alkaline environment that is incompatible with survival of bacteria in root canals. It also promotes the action of resorption cells, which may favor PDL repair after elimination of pathogenic agents. ${ }^{3}$ Another important property of $\mathrm{Ca}(\mathrm{OH})_{2}$ is that, in addition to eliminating microorganisms, it causes degradation of bacterial toxins capable of maintaining a toxic effect. ${ }^{17}$

The results of the present study confirm the excellent properties of $\mathrm{Ca}(\mathrm{OH})_{2}$, since no inflammatory root resorption was observed in the teeth filled with this material. An interesting finding was a higher incidence of ankylosis in the $\mathrm{Ca}(\mathrm{OH})_{2}$ - treated group compared to the MTA-treated group ( $p=0.004)$. This may be attributed to the faster and continuous alkalinization of dentin substrate produced by the $\mathrm{Ca}(\mathrm{OH})_{2}$ paste, which temporarily inhibits the action of clastic cells., ${ }^{3,18}$ However, the progression of dentoalveolar ankylosis into replacement root resorption occurs as a natural consequence of the typical phenomena involved in bone biopathology ${ }^{19}$ The velocity of this progression and the velocity of replacement resorption may vary depending on the persistence and frequency of the inductor stimulus, in addition to probable associations with concomitant inflammatory processes resulting from the traumatic injury itself or infections of endodontic or periodontal origins. ${ }^{1,14,19}$
Previous studies that evaluated the response of periapical tissues to MTA have found a small number of inflammatory cells and the formation of a fibrous capsule in teeth treated with MTA. ${ }^{6}$ Another frequent finding is the presence of newly formed cementum on the material surface. ${ }^{6,10,11}$ The findings of studies with gingival fibroblasts regarding the ability of MTA to induce periodontal regeneration, new cementum formation and pulp repair have suggested that this material is capable of stimulating the production of transformation growth factor (TGF), which plays a key role in regulating cell response, including cell growth and differentiation. ${ }^{11}$

In the present study, two specimens of the MTA group presented newly formed cementum in contact with the filling material, promoting a biological seal of the main apical foramen. This result confirms the hypothesis raised by authors of previous studies ${ }^{10,11}$ because, in the present study, the root-adhered PDL remnants were removed prior to tooth replantation.

When endodontic therapy is started 7 days after replantation, in cases of immediate replantation, or is performed with the tooth out of the socket, in cases of delayed replantation, the $\mathrm{Ca}(\mathrm{OH})_{2}$ intracanal dressing should be left in place for 1 month and then the definitive filling can be performed. ${ }^{13}$ However, when endodontic therapy is initiated after inflammatory root resorption had started, leaving the $\mathrm{Ca}(\mathrm{OH})_{2}$ intracanal dressing in place for a longer period of time is recommended until the resorption process ceases. ${ }^{2}$

In spite of its excellent biological properties, $\mathrm{Ca}(\mathrm{OH})_{2}$ has some disadvantages, such as a longer treatment time, the need to change the intracanal dressing and the weakening of the dental structure when left in place for prolonged periods. ${ }^{3}$ This weakening of the dental structure may be accounted for by the high alkalinity of this material, which may neutralize, dissolve or denature components of the dentin organic matrix, such as acid proteins and proteoglycans, which contain phosphate and carboxylic groups that act as binding agents between the hydroxyapatite crystals and the collagen fibers. ${ }^{9}$ When a long-term intracanal dressing is needed, MTA may have advantages over $\mathrm{Ca}(\mathrm{OH})_{2}$, e.g., treatment duration is shortened and the tooth can be restored in the same session, reducing the possibility of fracture 
and coronal leakage. Moreover, MTA does not affect the mechanical properties of dentin ${ }^{9,20}$ and presents good biocompatibility. $3,6,10,11$

When extensive PDL damage or necrosis occurs, the development of ankylosis and replacement root resorption is expected..$^{19}$ In these cases, new alveolar bone is formed and deposited in the space previously occupied by the PDL fibers that were lost, and the root is progressively resorbed and replaced by bone tissue. ${ }^{19}$ It is thus important to use biocompatible root canal filling materials because this expected root resorption process will expose them to the periodontal tissues.

Marão et al. ${ }^{21}$ observed that the MTA that remains within the tissues after the occurrence of replacement root resorption following delayed replantation caused a less pronounced inflammatory reaction and a higher rate of bone formation compared to $\mathrm{Ca}(\mathrm{OH})_{2}$.

The biocompatibility of MTA used in direct contact with cell cultures has been demonstrated. In vitro studies

\section{References}

1. Andreasen JO, Borum MK, Jacobsen HL, Andreasen FM. Replantation of 400 avulsed permanent incisors. 2. Factors related to pulpal healing. Endod Dent Traumatol. 1995 Apr;11(2):59-68.

2. Blomlöf L, Lengheden A, Lindskog S. Endodontic infection and calcium hydroxide- treatment. Effects on periodontal healing in mature and immature replanted monkey teeth. J Clin Periodontol. 1992 Oct;19(9 Pt 1):652-8.

3. Estrela C, Holland R. Calcium hydroxide: study based on scientific evidences. J Appl Oral Sci. 2003 Dec;11(4):269-82.

4. Torabinejad M, Chivian N. Clinical applications of mineral trioxide aggregate. J Endod. 1999 Mar;25(3):197-205.

5. Faraco Júnior IM, Holland R. Response of the pulp of dogs to capping with mineral trioxide aggregate or a calcium hydroxide cement. Dent Traumatol. 2001 Aug;17(4):163-6.

6. Holland R, Mazuqueli L, Souza V, Murata SS, Dezan Júnior E, Suzuki P. Influence of the type of vehicle and limit of obturation on apical and periapical tissue response in dogs' teeth after root canal filling with mineral trioxide aggregate. J Endod. 2007 Jun;33(6):693-7.

7. Torabinejad M, Hong CU, Lee SJ, Monsef M, Pitt Ford TR. Investigation of mineral trioxide aggregate for root-end filling in dogs. J Endod. 1995 Dec;21(12):603-8.

8. Torabinejad M, Hong CU, McDonald F, Pitt Ford TR. Physical and chemical properties of a new root-end filling material. J Endod. 1995 Jul;21(7):349-53. have reported that MTA had no adverse effect on cell growth and did not cause cell death. ${ }^{10,11}$ Laboratory study findings may explain the successful use of MTA in several in vivo investigations, confirming the biocompatibility and clinical applicability of this product. . $, 6,7,21,22^{2}$

Despite the excellent biological properties of MTA, its use as a filling material may have some disadvantages that should be considered. The physical properties of MTA render handling difficult, and can even make it impossible to remove the material if endodontic retreatment is needed. ${ }^{6,23}$ Tooth crown discoloration, attributed to a possible chemical reaction, may occur even with use of white $\mathrm{MTA}^{24}$ and the higher cost of MTA compared with $\mathrm{Ca}(\mathrm{OH})_{2}$ is another factor to be considered.

\section{Conclusion}

In conclusion, MTA was similar to calcium hydroxide in the prevention of root resorption, and its use resulted in a smaller area of ankylosis.

9. Rosenberg B, Murray PE, Namerow K. The effect of calcium hydroxide root filling on dentin fracture strength. Dent Traumatol. 2007 Feb;23(1):26-9.

10. Oviir T, Pagoria D, Ibarra G, Geurtsen W. Effects of gray and white mineral trioxide aggregate on the proliferation of oral keratinocytes and cementoblasts. J Endod. 2006 Mar;32(3):210-3.

11. Guven G, Cehreli ZC, Ural A, Serdar MA, Basak F. Effect of mineral trioxide aggregate cements on transforming growth factor beta1 and bone morphogenetic protein production by human fibroblasts in vitro. J Endod. 2007 Apr;33(4):447-50.

12. Tanomaru-Filho M, Tanomaru JMG, Barros DB, Watanabe E, Ito IY. In vitro antimicrobial activity of endodontic sealers, MTAbased cements and Portland cement. J Oral Sci. 2007 Mar;49(1):41-5.

13. Andersson L, Andreasen JO, Day P, Heithersay G, Trope M, DiAngelis JA, et al. International Association of Dental Traumatology guidelines for the management of traumatic dental injuries: 2. Avulsion of permanent teeth. Dent Traumatol. 2012 Apr;28(2):88-96.

14. AndreasenJO. Relationship between surface and inflammatory resorption and changes in the pulp after replantation of permanent incisors in monkeys. J Endod. 1981 Jul;7(7):294-301.

15. Seux D, Couble ML, Hartmann DJ, Gauthier JP, Magloire H. Odontoblast-like cytodifferentiation of human dental pulp cells in vitro in the presence of a calcium hydroxidecontaining cement. Arch Oral Biol. 1991;36(2):117-28. 
16. Holland R, Pinheiro CE, Mello W, Nery MJ, Souza V. Histochemical analysis of the dogs' dental pulp after pulp capping with calcium, barium and strontium hydroxides. J Endod. 1982 Oct;8(10):444-7.

17. Safavi KE, Nichols FC. Effect of calcium hydroxide on bacterial lipopolysaccharide. J Endod. 1993 Feb;19(2):76-8.

18. Mori GG, Moraes IG, Garcia RB, Borro LC, Purificação BR. Microscopic investigation of the use of gallium nitrate for root surface treatment in rat teeth submitted to delayed replantation. Braz Dent J. 2007;18(3):198-201.

19. Hammarström L, Blomlöf L, Lindskog S. Dynamics of dentoalveolar ankylosis and associated root resorption. Endod Dent Traumatol. 1989 Aug;5(4):163-75.

20. Andreasen JO, Munksgaard EC, Bakland LK. Comparison of fracture resistance in root canals of immature sheep teeth after filling with calcium hydroxide or MTA. Dent Traumatol. 2006 Jun;22(3):154-6.
21. Marão HF, Panzarini SR, Aranega AM, Sonoda CK, Poi WR, Esteves JC, et al. Periapical tissue reactions to calcium hydroxide and MTA after external root resorption as a sequela of delayed tooth replantation. Dent Traumatol. 2012 Aug;28(4): 306-13.

22. Hansen SW, Marshall JG, Sedgley CM. Comparison of intracanal EndoSequence Root Repair Material and ProRoot MTA to induce $\mathrm{pH}$ changes in simulated root resorption defects over 4 weeks in matched pairs of human teeth. J Endod. 2011 Apr;37(4):502-6.

23. Boutsioukis C, Noula G, Lambrianidis T. Ex vivo study of the efficiency of two techniques for the removal of mineral trioxide aggregate used as a root canal filling material. J Endod. 2008 Oct;34(10):1239-42.

24. Watts JD, Holt DM, Beeson TJ, Kirkpatrick TC, Rutledge RE. Effects of $\mathrm{pH}$ and mixing agents on the temporal setting of tooth-colored and gray mineral trioxide aggregate. J Endod. 2007 Aug;33(8):970-3. 